\title{
Instagram Fatwa: Analisis terhadap Pesan Fatwa dalam Akun Instagram @Dakwahquransunnah
}

\author{
Hilman Fauzi Patahillah \\ Pascasarjana, UIN Sunan Kalijaga Yogyakarta, Indonesia \\ (email: hilmanfauzi0808@gmail.com)
}

\begin{abstract}
In the new media era, information technology has become a multi-functional thing among its users. Especially the Instagram media which has become a new arena for Islamic unity to broadcast its teachings. Instagram has become a forum for Islamic unity in disseminating its fatwa. The purpose of this research is to find out how fatwas are discouraged on Instagram social media. The results of his research are that in the era of new media, it is precisely still reflective of the teachings of purification of religion, because the influence of new media talks very little about social and political matters, and among the followers there is a shift in authority, exactly not up to date on new issues, and always raises old topics that are impressed ancient.
\end{abstract}

\section{Keywords:}

Online Fatwa, Social Media, Instagram, Authority Shifting

\begin{abstract}
Abstrak
Di era media baru, teknologi informasi sudah menjadi hal yang multi fungsi di kalangan penggunanya. Khususnya media Instagram yang menjadi arena baru bagi persatuan Islam mensyiarkan ajarannya. Instagram telah menjadi wadah persatuan Islam dalam menyebarluaskan fatwanya. Tujuan dari penelitian ini adalah untuk mengetahui bagaimana fatwa di wacanakan di media sosial Instagram. Hasil penelitiannya adalah di era media baru persis tetap refresentatif dengan ajaran pemurnian agamanya, karena pengaruh media baru persis sedikit berbicara sosial dan politik, dan dikalangan followers terjadi pergeseran otoritas, persis kurang up to date terhadap isu baru, persis juga selalu mengangkat topik lama yang terkesan kuno.
\end{abstract}

Kata Kunci:

Fatwa Online, Media Sosial, Instagram, Pergeseran Otoritas 


\section{Pendahuluan}

Internet telah banyak membentuk penggunanya secara tidak sadar, lingkungan baru internet yang dalam hal ini adalah media sosial seolah menjadi lingkungan baru yang bisa berpengaruh besar, terutama dalam hal refresentasi konten di dalamnya. Hal ini menjadi mungkin jika saya mengatakan bahwa transformasi nilai-nilai, ideologi, prinsip, telah bebas konsumsi sesuai dengan apa yang mereka butuhkan, ini bisa saja disebut sebagai pembentukan identitas di media sosial, pembentukan identitas yang di maksud bisa saja memungkinkan manusia sebagai 'masyarakat jejaring'.

Dalam jagat komunikasi, masyarakat jejaring dicirikan dengan pola jejaring, fleksibilitas rekombinasi kode-kode, dan komunikasi simbolis sesaat. Ia merupakan kebudayaan yang secara umum berlangsung dan terintegrasi dengan sistem yang mengalami diversifikasi dari media elektronik, termasuk internet. Ekspresi kebudayaan semakin dipertajam dengan jaringan-jaringan ini: hiperteks elektronik, yang dibentuk oleh televisi, radio, media cetak, film, video, seni, dan komunikasi internet dalam apa yang disebutnya sebagai "multimedia system". Sistem multimedia tidak dicirikan dengan pesan satu arah kepada massa sebagai audiens. Media dalam masyarakat jejaring menampilkan beragam saluran komunikasi dengan meningkatnya sifat interaktivitas dari media tersebut ${ }^{2}$.

Berbicara media baru, penulis akan mengangkat media jejaring sosial Instagram yang mempunyai fungsi untuk berbagi foto, video, tulisan, atau konten untuk menggerakan manusia. Menarik diidentifikasi mengenai fungsi instagram sebagai alat untuk dijadikan suatu gerakan, salah satu gerakannya adalah gerakan keagamaan. Tentu ini menjadi fokus penting dalam tulisan ini, karena Instagram telah menjadi tempat bertransformasi gerakan keagamaan.

\footnotetext{
${ }^{1}$ Moch. Fakhruroji, “Dakwah Di Era Media Baru” Teori Dan Aktivisme Dakwah Di Internet.(Simbiosa Rekatama Media,2017) 187

${ }^{2}$ Moch. Fakhruroji, “Dakwah Di Era Media Baru” Teori Dan Aktivisme Dakwah Di Internet, 23
} 
Media sebagai alat publik yang dijadikan sebagai ruang baru untuk mentransformasi pesan-pesan agama. Perpindahan tempat penyampaian pesan agama dari tradisional ke ruang baru yang dalam hal ini adalah media sebagai medium dakwah, jika media sebagai alat maka diantara agama dan media tidak bisa disatukan karena merupakan entitas yang berbeda. Maka anggapan terakhir bahwa media sebagai "pelayan" dan agama sebagai "tuan"3.

Transformasi yang telah terjadi telah mempengaruhi penggunaan internet, contohnya agama dalam segi tindakan dan praktik nilai-nilai Islam di refresentasikan di dunia yang lebih bebas konsumsi, dan pada cara masyarakat Islam memersepsikan dan merefresentasikan dirinya ${ }^{4}$.

Dalam akun Instagram @dakwahquransunnah, akun tersebut merupakan akun kelompok organisasi Islam Persatuan Islam (Persis) yang hari ini telah memiliki followers sebanyak $13,4 \mathrm{k}$ dan telah mengunggah konten sebanyak 145, dan telah mengikuti sebanyak 846 yang kesemuanya merupakan akun jejaring komunitas Persis yang cakupannya lebih kecil.

Dengan beberapa aspek yang menjadi latar belakang dari penelitian ini, maka fokus penelitian ini akan berdiskusi tentang wacana bagaimana media sosial digunakan dalam akun Instagram @dakwahquransunnah milik kelompok organisasi Islam persis.

\section{Metode penelitian}

Metode yang digunakan dalam tulisan ini dengan cara etnografi virtual, yaitu dengan cara terlibat langsung dengan lokasi, subjek dan objek penelitian dengan cara memahami dan mengamati konteks secara mendalam melalui empat level, yakni: ruang media, dokumen media, objek media, dan pengalaman pengguna. ${ }^{5}$ Penelitian

\footnotetext{
${ }^{3}$ Moch. Fakhruroji, “Dakwah Di Era Media Baru” Teori Dan Aktivisme Dakwah Di Internet, 16. ${ }^{4}$ Moch. Fakhruroji, "Dakwah Di Era Media Baru” Teori Dan Aktivisme Dakwah Di Internet, 127.

${ }^{5}$ Moch. Fakhruroji., \& Muchtar, K. Campaigning \#golkarsolid: Branding Image Strategy of Golkar Party on Social Media. Atlantis Press. 2018, 210-14.
} 
hanya mengidektifikasi tentang efektivitas otoritas keagamaan dan representasi Persis yang dilakukan di media sosial Instagram dengan berfokus pada data unggahan yang ada dalam akun @dakwahquransunnah secara mendalam.

\section{Kajian pustaka}

Kajian mengenai wacana pemanfaatan media baru Instragram, dalam hal ini terdapat beberapa penelitian terdahulu yang cenderung berisi tentang geliat akun Instagram. Kecenderungan pertama adalah akun yang berisikan aktifitas personal dan kecenderungan kedua akun yang merepresentasikan sebagai komunitas.

Kecenderungan pertama mengenai akun personal terdapat pada penelitian yang dilakukan oleh Nabila Triani Putri terhadap salah seorang selebgram dengan akun @NADYAROSMANIA. Nabila mengatakan bahwa dengan banyaknya follower, akun tersebut dijadikan sebagai arena personal branding dengan tujuan dan kepentingan tertentu. ${ }^{6}$

Kecenderungan kedua berbeda dengan penelitian Nabila di atas, penelitian yang dilakukan oleh Aflahal Misbah" dengan judul "Kesenangan dan Otoritas Keagamaan: Sosialiasi Anti Musik Di Instagram", Aflahal mengatakan dalam penelitiannya bahwa media sosial Instagram telah dijadikan sebagai jaringan untuk mengkampanyekan fatwa dan ajaran tertentu. Hadirnya agama dalam media sosial menjadi fenomena baru hari ini yang dilakukan oleh komunitas yang mengatasnamakan salafi.

Kecenderungan serupa yang mengatasnamakan kelompok atau komunitas juga dilanjutkan oleh penelitiannya Moch Fakhruroji ${ }^{8}$ dengan judul “Belajar Al-Quran kapan saja, Dimana Saja: kampanye platform Qurancall PPPA Darul Quran melalui Instagram @qurancall”. Penelitian tersebut berisi tentang gerakan agama melalui

\footnotetext{
${ }^{6}$ Nabila Triyani P, "Personal Branding Selebgram Melalui Akun Instagram: studi deskriptif pada akun @) NADYAROSMANIA ACCOUNT" jurnal Fakultas Komunikasi dan Bisnis Universitas Telkom. $2019,77$.

${ }^{7}$ Aflahal Misbah, "Kesenangan dan Otoritas Keagamaan: Sosialisasi Anti Musik di Instagram".Jurnal Masyarakat \& Budaya. Vol.21 No. 2. 2019, 149.

${ }^{8}$ Moch Fakhruroji, “Belajar Al-quran Kapan Saja, Dimana Saja: Kampanye Platform QuranCall PPPA Darul Quran melalui Instagram”. UIN Sunan Gunung Djati, Bandung. Vol. 2 No. 2. 2020, 397.
} 
Instagram yang dilakukan oleh PPPA Darul Quran dengan cara mengkampanyekan kajian Al-Quran yang bebas tempat dan waktu, juga upaya mensosialisasikan pesanpesan agama yang dapat menginspirasi follower-nya.

Beberapa penelitian di atas menjadi titik tolak berangkatnya penelitian ini, dengan melanjutkan kajian penelitian tentang gerakan komunitas yang menjadikan akun Instagram sebagai wahana baru dengan hadirnya agama di kalangan pengguna media sosial. Yang menjadi kebaruan dari penulisan ini adalah kajian mengenai kelompok PERSIS yang menggerakan akun@dakwahquransunnah menjadi sebuah arena yang dinamis dan fleksibel.

\section{Instagram}

Instagram sebagai salah satu media sosial yang mempunyai beberapa fitur untuk memfasilitasi penggunanya. Berikut bebrapa fitur yang ada di instagram: Fitur Foto

Salah satu fitur yang ada pada instagram dan menjadi fitur utama para penggunanya, para pengguna instagram bisa berswa foto, selfi, foto grup, ataupun berbentuk tulisan dalam fitur tersebut, para pengguna instagram dengan berbagai gaya dapat menggunakan pula berbagai efek menarik pada fitur ini dan mengunggahnya melalui instagram.

\section{Fitur Video}

Sama halnya dengan foto, video juga merupakan fitur pada instagram yang banyak digunakan oleh para penggunanya untuk berbagi moment ataupun kejadian. Dan hebatnya, pada fitur ini kita bisa tahu berapa banyak orang yang menonton video kita.

Caption

Caption merupakan hal penting yang menjadi salah satu faktor penunjang dalam fitur instagram baik untuk foto ataupun video, caption berbentuk tulisan yang mengandung pesan. Biasanya pesan dalam caption dibuat dengan semenarik mungkin. Dengan menggunakan caption yang menarik, pengguna dapat 
menyampaikan pesan yang menginspirasi, memikat, atau mengajak, para followers nya. Caption bisa saja berisi penjelasan atau arti, baik untuk foto ataupun video yang diunggah. Di sisi lain caption juga dapat menggambarkan pesan yang bahkan sama sekali tidak berhubungan dengan foto atau video.

Tanda Pagar (hashtag)

Hashtag adalah sebuah kata kunci kecil dengan tanda pagar $(\#)^{9}$, hashtag sangat populer di berbagai platform media sosial, hashtag berfungsi untuk menandai sesuatu hal yang penting yang tengah menjadi topik perbincangan di kalangan warga net. Perbincangan tersebut dapat menjadi trending topik apabila para pengguna instagram semakin banyak yang menggunakan hashtag tersebut. Terlebih pada platform media sosial lainnya dengan hashtag yang sama pula.

Followers

Follower adalah pengikut kita dalam akun media sosial instagram, ketika kita mengunggah foto atau video di instagram, maka unggahan kita akan secara otomatis masuk dan berada pada layar beranda para followers. Selain itu, fungsi followers juga adalah yang memberikan sebagian besar like atau komentar terhadap unggahan kita.

\section{Jejaring Sosial}

Jejaring sosial adalah untuk menghubungkan antara satu akun media sosial dengan akun media sosial lainnya di dalam satu device. Ketika pengguna pada media instagram akan mengunggah foto, video atau konten lainnya maka secara otomatis akan muncul option yang mengarahkan kita pada pilihan apakah konten yang akan diunggah hanya dibagikan pada media sosial instagram saja atau akan dibagikan pula dengan platform media sosial lainnya. sehingga pengaturan ini memudahkan pengguna media sosial untuk masuk pada semua jejaring sosial.

\footnotetext{
${ }^{9}$ Mulyana, Deddy. Ilmu Komunikasi Suatu Pengantar. Bandung:PT. Remaja Rosdakarya. 2017, 281.
} 
Like

Like adalah tanda suka dengan bentuk hati berwarna merah sebagai tanda respon positif atau timbal balik dari followers. Berdasarkan pengalaman penulis, tanda like mempunyai pengaruh besar terhadap orang yang di like dan orang yang memberikan like. Dan pengaruh ini diantaranya adalah perasaan senang, dan merasa termotivasi untuk membuat unggahan atau konten lainnya yang lebih menarik sehingga mendapatkan like yang lebih banyak dan menarik followers yang lebih banyak pula.

\section{Hasil dan pembahasan}

Lebih awal akan dibahas Beberapa konsepsi pemikiran yang menjadi dasar terbentuknya organisasi Islam PERSIS ${ }^{10}$ sebagai berikut:

\section{Konsep Khurafat Dan Takhayul}

Mengharapkan sesuatu untuk menciptakan sebuah keamanan dari hal gaib merupakan contoh dari praktik khurafat, biasanya dilakukan dengan waktu dan tempat yang telah ditentukan, seperti membuat persembahan di setiap malam jum'at atau malam selasa. Hal ini sama sekali tidak melibatkan nama tuhan dalam dirinya, bagi agama Islam yang mempunyai ideology Al-Qur'an dan Al-Hadist seperti Persis hal tersebut bukanlah perbuatan yang masuk akal. Kemudian yang dimaksud dengan takhayul adalah mengikuti ajaran yang telah digambarkan oleh kebiasaan leluhur atau pendahulunya ${ }^{11}$.

Kedua hal di atas menjadi perhatian yang amat serius bagi agama Islam, karena ini merupakan sesuatu yang bertabrakan dengan ketauhidan yang mengharuskan seseorang semata-mata patuh terhadap Allah SWT. Berbicara mengenai ketauhidan terkhusus Persis tidak ada tawar menawar, seperti contohnya kepercayaan terhadap benda mati yang dipercaya bisa mendatangkan sesuatu. Mengenai hal demikian,

${ }^{10}$ Dadan Wildan Anas, Anatomi Gerakan Dakwah Persatuan Islam, 265.

${ }^{11}$ Risalah, Bandung: Da'watul Islam \& Warta Jan'iyah PP. Persatuan Islam,th.XVIII No.184, 27. 
Peersis tegas mengatakan bahwa kepercayaan itu merupakan animis yaitu kepercayaan kuno bangsa Indonesia.

Nurcholis Majid mengilustrasikan kedua hal di atas bahwa pelaku yang melakukan tindakan khurafat dan takhayul bukanlah dari golongan orang yang primitif, melainkan orang-orang kelas menengah ke atas di tengah perkotaan, mereka mengadakan selametan dengan membawakan bacaan-bacaan dengan perantara makhluk selain Allah SWT tetapi ada nuansa agama di dalamnya. Maka tidak ayal jika banyak para pejabat tinggi mendatangi orang pintar, meminta pada roh ataupun kuburan.

\section{Konsep Syirik}

Hasan menggambarkan contoh syirik sebanyak 23 macam, yaitu:

1. Menyembah benda mati, patung binatang

2. Mengharapkan sesuatu kepada makhluk selain Allah dalam hal-hal yang mistis

3. Takut terhadap sesuatu seperti takutnya terhadap Allah SWT.

4. Menyembelih hewan tidak karena Allah

5. Melakukan sumpah (pocong)

6. Meyakini ulama atau guru tanpa didasari Al-Qur'an dan Al-Hadits

7. Menghalalkan sesuatu yang haram

8. Mengharamkan sesuatu yang halal

9. Membayangkan sosok guru ketika berdzikir atau berdo'a

10. Menyandingkan nabi dengan nama lain ketika menyeru di waktu sempit

11. Sesuatu dianggap sial

12. Beribadah yang tak berdasar dari Allah

13. Meminta hujan kepada selain Allah

14. Kuburan dan kayu dianggap memberikan keberkahan

15. Menganggap keramat kepada benda-benda dan merehdahkan diri kepadanya

16. Beribadah dengan harapan akan pujian 
17. Beranggapan bahwa ada yang berkuasa selain Allah

18. Menyandingkan nama Allah SWT dengan makhluk ciptaannya

19. Menghina agama Allah

20. Anggapan bahwa agama tidak berguna

21. Menganggap manusia sebagai perantara menuju Allah

22. Menganggap arwah sebagai perantara menuju Allah

23. Menganggap ada nabi terakhir setelah nabi Muhammad Saw.

\section{Hasan dan lahirnya Al-Qur'an dan Al-Sunnah sebagai sumber Syari'at}

Persis kerap kali dikaitkan dengan nama A. Hasan, padahal pada faktanya A. Hasan bukanlah pendiri Persis, melainkan pemikirannya yang selalu diidentikan dengan Persis. Melalui pemikirannya, A. Hasan seolah membawa kepada ideology Persis sebagai organisasi puritan ${ }^{12}$.

Jejak A. Hasan di atas disampaikan oleh Syafiq A. Mughni, yang mengatakan bahwa pokok pemikiran Persis murni hasil dari tela'ah terhadap Al-Qur'an dan AlHadits, ijma dan kiyas yang tidak bertdiri sendiri, melainkan melalui tahapan musyawarah. Begitu pula dengan aspek hukum yang sumbernya tidak terbatas. A. Hasan menuturkan Al-Qur'an, sebagai wahyu dan bacaan yang merupakan pedoman utama umat Islam. Sedangkan Hadits merupakan kabar, perbuatan, tindakan yang dilakukan oleh Rasul. ${ }^{13}$

\section{Konsep Bid'ah}

Sebagaimana telah diulas dibagian sebelumnya mengenai khurafat dan takhayul yang merusak ketauhidan, hail ini berbeda dengan Bid'ah yang merupakan upaya perubahan atau penambahan dalam praktek ibadah kepada Allah, yang mana segala

\footnotetext{
${ }^{12}$ Dadan Wildan Anas, Anatomi Gerakan Dakwah Persatuan Islam. 285.

${ }^{13}$ A. Hassan, Risalah Al-Qur'an dan As-Sunnah,1972, 11-12.
} 
jenis aspek yang berkaitan dengan ketuhanan merupakan hak mutlak milik Allah sebagai suatu syari'at Islam ${ }^{14}$.

T.M. Hasbi Ash-Shiddieqy ${ }^{15}$ menuturkan bahwa Bid'ah adalah praktik yang berhubungan dengan perubahan peribadatan untuk menciptakan sebuah syari'at di dalam agama. Maka dengan tegas dikatakan bahwa Bid'ah lebih berbahaya daripada maksiat.

Penelitian ini menjabarkan beberapa pengalaman penulis setelah mengikuti dan menganalisa akun instagram @dakwahquransunnah selama kurang lebih $2^{\text {th }}$. Beberapa hal yang menjadikan hasil identifikasi akan diuraikan berdasarkan pengamatan dan pengujian teori yang terdahulu.

\section{Fatwa}

konsep fatwa itu sendiri telah berubah seiring dengan berjalannya waktu. Ruang lingkup fatwa tidak terbatas pada wilayah hukum saja, tetapi juga menyangkut persoalan politik, ekonomi, etika ${ }^{16}$. Dalam bagian ini akan mengeksplorasi contoh kasus fatwa yang di keluarkan oleh persis dan kaitannya dengan peran pemuda persis mengenai fatwa.

Pelaku yang merumuskan fatwa di dalam organisasi Persis adalah Dewan Hisbah Persis Pusat. Hari ini media baru telah menjadi mendium bagi organisasi Persis untuk mensosialisasikan fatwanya. Dari 145 unggahan yang mencakup foto dan video sampai hari ini di dominasi oleh konten yang berisi fatwa Persis.

${ }^{14}$ Dadan Wildan Anas, Anatomi Gerakan Dakwah Persatuan Islam. 302.

${ }^{15}$ Majalah Hudjdjatul Islam, "Bid'ah lebih berbahaya dari Ma'shiat", Bandung: Persatuan Islam, 1956. Hlm:26-29

16 Sunarwoto. Contesting religious authority: A study on Dakwah Radio In Surakarta, Indonesia. Desertasi, Tilburg University, 2015, hlm 200. 
Gambar 1. Poster Hukum Perayaan Maulid Menurut A. Hassan

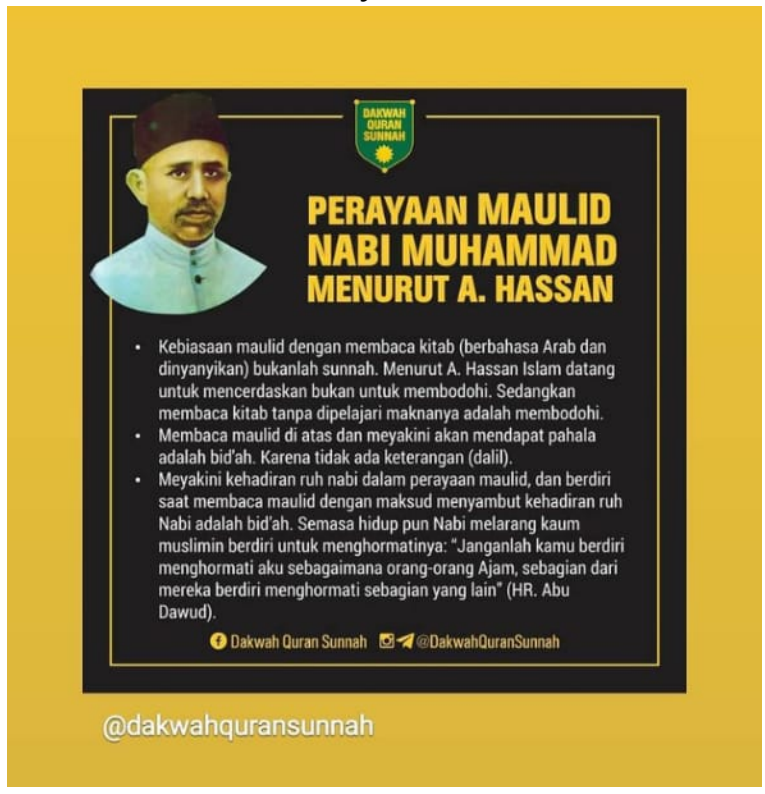

Sumber: Akun instagram @dakwahquransunnah

Foto yang berisikan fatwa Persis di atas diunggah pada tanggal 6 November 2019. Bagi penulis, foto yang diunggah di atas terkesan Persis itu sulit menemui kebaruan dalam kontennya, ketegasan tentang konsep bid'ah yang di contohkan di atas mengenai perayaan Maulid Nabi. Sudah jauh disosialisasikan melalui dakwah mimbar dengan cara ceramah.

Unggahan Persis mengenai hukum Maulid Nabi mendapatkan 786 like dan 35 komentar dari para warga net. Akan tetapi, yang menjadi sorotan disini adalah Persis tidak membalas komentar apapun dalam unggahannya tersebut dan Persis terkesan satu arah dalam menyampaikan fatwanya di media sosial Instagram. 35 komentar tersebut kebanyakan isinya adalah ijin share (meminta ijin kepada admin untuk membagikan kembali unggahan @dakwahquransunah), artinya permintaan ijin share yang dilakukan oleh warga net itu menunjukkan bahwa secara tidak langsung fatwa Persis telah diterima dengan kata lain terjadinya pergeseran otoritas di media.

Oleh karena itu, berbicara mengenai internet dan media sosial tentu tidak hanya terfokus pada penyampai, melainkan juga aktivitas mad'u atau audiens yang bisa berperan aktif di dalamnya. Bagi masyarakat jejaring, ketika mereka 
mendapatkan pesan melalui media sosial atau jejaring sosial yang lainnya bisa dengan langsung share teman, sahabat, atau kerabat secara sukarela karena dia menganggap hal itu sebagai sesuatu yang bermanfaat dan orang lain juga perlu mendapatkan hal tersebut. Share pesan yang dilakukan itu merupakan perlakuan seseorang yang sebetulnya dia bukan da'i. hal ini yang menjadi dasar penjelasan bahwa semua orang menjadi berhak untuk mengendalikan jejaraing nya tanpa ada validasi apapun. Hal ini disebut juga dengan kekuasaan atau otoritas di media sosial ${ }^{17}$.

Burhanuddin dan Zulkifli mengatakan aspek penting mengenai persoalan keagamaan terutama yang berurusan dengan otoritas keagamaan. Di era media baru, otoritas keagamaan mengalami pergeseran yang amat terasa, jika melihat pada periode tradisional hubungan antara pengikut dengan tokoh pemuka agama seperti kiai, ulama, ustadz, sangat kental dan dijadikan satu-satunya sumber rujukan dalam menjalankan agama dalam bentuk tindakan dan segala aspek dalam tatanan bermasyarakat. Hari ini, pengikut tradisional yang baru saja disinggung telah menemukan ruang baru mengenai otoritas, secara personal mereka bisa menemukan sendiri apa yang menjadi kebutuhan dia dalam bertindak baik secara rohani ataupun jasmani melalui media sosial yang seolah paket lengkap di dalamnya ${ }^{18}$.

Berbicara mengenai internet dan media sosial tentu tidak hanya terfokus pada penyampai, melainkan juga aktivitas mad'u atau audiens yang bisa berperan aktif di dalamnya. Bagi masyarakat jejaring, ketika mereka mendapatkan pesan melalui media sosial atau jejaring sosial yang lainnya bisa dengan langsung share teman, sahabat, atau kerabat secara sukarela karena dia menganggap hal itu sebagai sesuatu yang bermanfaat dan orang lain juga perlu mendapatkan hal tersebut. Share pesan yang dilakukan itu merupakan perlakuan seseorang yang sebetulnya dia bukan da'i. hal ini yang menjadi dasar penjelasan bahwa semua orang menjadi berhak untuk

\footnotetext{
${ }^{17}$ Moch. Fakhruroji, “Dakwah Di Era Media Baru” Teori Dan Aktivisme Dakwah Di Internet.(Simbiosa Rekatama Media,2017) 28.

${ }^{18}$ Zulkifli, The ulama in Indonesia: Between Religious Authority and Symbolic Power. Jurnal Miqat, vol. XXXVII N0. 1 januari-juni 2013, 181.
} 
mengendalikan jejaraing nya tanpa ada validasi apapun. Hal ini disebut juga dengan kekuasaan atau otoritas di media sosial ${ }^{19}$.

Gambar 2. Poster Hukum Menggelar Acara Tujuh Bulanan

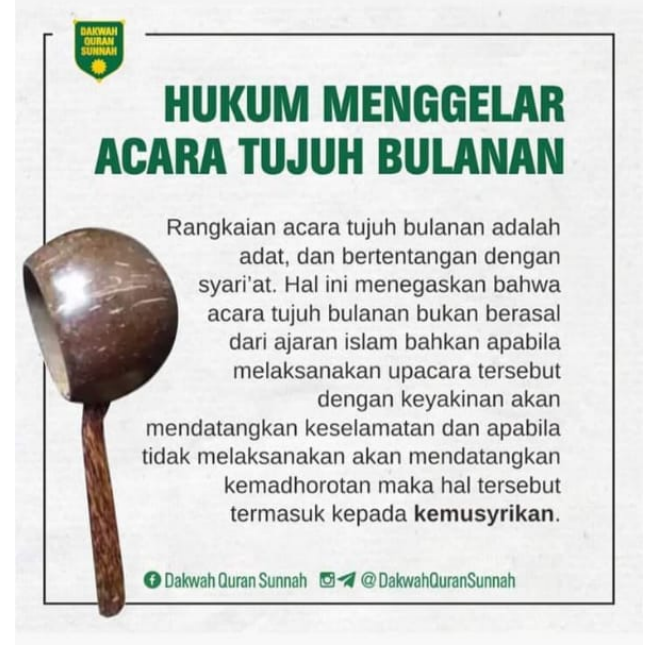

Sumber: Akun instagram @dakwahquransunnah

Foto yang berisikan fatwa Persis mengenai Syukuran Tujuh Bulanan di atas diunggah pada tanggal 24 Januari 2020. Dalam unggahan ini terdapat 779 like dan 32 komentar dari warga net. Menariknya, postingan ini mengundang banyak komentar warga net untuk berduskusi bahkan sempat ada yang berdebat tentang acara syukuran tujuh bulanan. Parahnya lagi, ada kelompok organisasi Islam lain yang kontra terhadap unggahan tersebut. Dalam postingan ini penulis bisa melihat bahwa kolom komentar sudah menjadi sebuah medium untuk berkontestasi persoalan dalam hal wacana keagamaan.

Dalam unggahan di atas mengenai acara Syukuran Tujuh Bulanan, Persis mengeluarkan fatwa bahwa hal tersebut termasuk dalam kemusyrikan. Sebagaimana telah diulas pada bagian sebelumnya tentang konsepsi syirik, yaitu meyakini sesuatu kepada selain Allah SWT. Menurut kelompok yang melakukan acara Tujuh Bulanan adalah berpendapat bahwa hal tersebut mendatangkan manfaat jika dilaksanakan dan akan terjadi marabahaya ketika tidak dilaksanakan.

${ }^{19}$ Moch. Fakhruroji, "Dakwah Di Era Media Baru” Teori Dan Aktivisme Dakwah Di Internet.(Simbiosa Rekatama Media,2017) 28. 
Berbeda dengan postingan sebelumnya, dalam kolom komentar diunggahan ini admin memberikan respon dengan membalas komentar para warga net. Hal ini menunjukkan bahwa terjadinya interaksi antara penyampai dan penerima pesan. Dalam situasi dan kondisi tertentu, dakwah beradaptasi sesuai dengan ruang dan waktu. Dalam konteks objek dakwah seperti mad'u atau audiens, ruang dan waktu lah yang mempengaruhi perubahan dalam pola dakwah, perubahan tersebut berkaitan dengan metodologi karakteristik dari dakwah itu sendiri. Khalayak dakwah selalu berada pada ruang dan waktu tertentu. Suatu kelompok khalayak pada tempat dan saat tertentu mungkin memiliki karakteristik yang berbeda dengan kelompok khalayak pada tempat dan saat yang lain ${ }^{20}$.

Gambar 3. Poster Hukum Menerima Makalah Tahlilan atau Sesajen

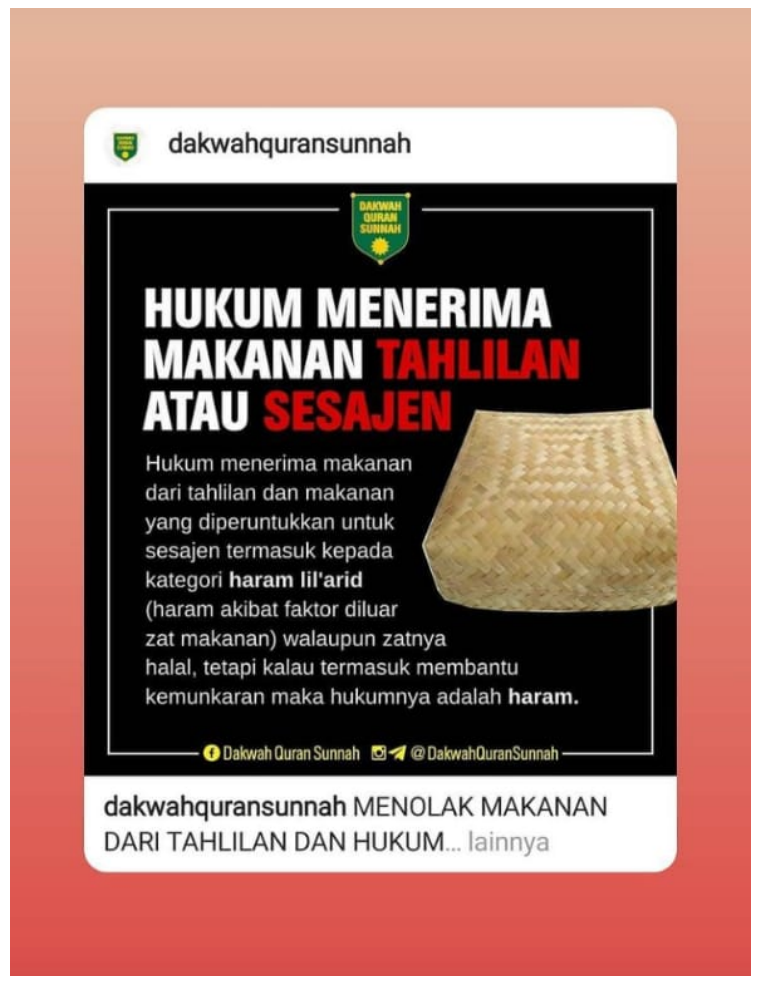

Sumber: Akun instagram @dakwahquransunnah

Foto yang berisikan fatwa Persis mengenai Tahlilan di atas diunggah pada tanggal 1 Februari 2020. Dalam unggahan ini terdapat 589 like dan 74 komentar dari warga net. Unggahan fatwa Persis di atas mengenai Tahlilan menjadi sorotan paling

${ }^{20}$ Moch. Fakhruroji, "Dakwah Di Era Media Baru” Teori Dan Aktivisme Dakwah Di Internet.(Simbiosa Rekatama Media,2017) 11. 
tinggi diantara ketiga unggahan yang penulis ambil sebagai ilustrasi. Dalam unggah ini mengundang banyak komentar warga net yang saling pro-kontra dan bahkan sampai berdebat. Dalam unggahan ini pula admin @dakwahquransunnah membalas komentar para warga net dan terjadi interaksi saling timbal balik.

Dalam unggahannya di atas Persis mengeluarkan fatwa bahwa Tahlilan ataupun menerima bingkisan tahlilan adalah termasuk haram. Haramnya menerima bingkisan tahlilan yang di kemukakan Persis karena makanan tersebut termasuk pada haram lil'arid, yaitu sebab haram di luar zat. Karena makanannya berasal dari proses tahlilan yang merupakan praktik bid'ah.

Jika berbicara dalam konteks dakwah, akun@dakwahquransunnah adalah $d a^{\prime} I$ dan follower atau warga net adalah mad'u. Dalam hal ini mad'u seperti mempunyai gerakan sendiri di dalam kolom komentar, sejalan dengan apa yang disampaikan oleh Fakhruroji yang memiliki pandangan terhadap hal tersebut menandai kematian Da'I, justru masyarakat jejaring memperlihatkan fenomena kebangkitan mad'u. jika menilik kembali dalil Barthes, "the death of the author" hal tersebut justru menyiratkan makna lain, yakni "the rise of the reader/audience" atau bangkitnya pembaca atau khalayak. Kematian pengarang yang kemudian membebaskan teks yang diproduksinya sehingga memiliki makna yang mengambang, pada saat yang sama justru mengungkapkan juga gagasan tentang meningkatnya kuasa pembaca atau khalayak untuk memaknai teks yang telah terbebas dari pengarang itu sendiri.

Oleh karena itu, berbicara mengenai internet dan media sosial tentu tidak hanya terfokus pada penyampai, melainkan juga aktivitas mad'u atau audiens yang bisa berperan aktif di dalamnya. Bagi masyarakat jejaring, ketika mereka mendapatkan pesan melalui media sosial atau jejaring sosial yang lainnya bisa dengan langsung share teman, sahabat, atau kerabat secara sukarela karena dia menganggap hal itu sebagai sesuatu yang bermanfaat dan orang lain juga perlu mendapatkan hal tersebut. Share pesan yang dilakukan itu merupakan perlakuan seseorang yang sebetulnya dia bukan da'i. hal ini yang menjadi dasar penjelasan bahwa semua orang 
menjadi berhak untuk mengendalikan jejaraing nya tanpa ada validasi apapun. Hal ini disebut juga dengan kekuasaan atau otoritas di media sosiall21.

\section{Representasi Persis}

Sebagai ruang baru bagi ekspresi keagamaan, internet memiliki potensi lanjutan bagi agama-agama untuk menyebarkan ajarannya. Internet tidak hanya berisikan media baru di dalamnya, tetapi juga bisa terlahir gerakan-gerakan dengan mengatasnamakan agama seperti agama Islam dan hal ini disebut dengan aktivisme dakwah. Bagi pengguna media yang beraktifitas di dalamnya untuk berdakwah, mereka bisa dengan bebas menyebar luaskan ajaran keIslamannya baik itu melalui website, blog, media sosial, atau sarana lainnya, hal ini secara tidak langsung bisa membentuk ruang baru dalam pembentukan identitas ${ }^{22}$.

Saat ini dunia nyata seolah tergantikan dengan adanya dunia virtual, hal ini akan mengancam keberlangsungan agama secara substansial. Namun, dunia virtual sebagai arena baru akan menjadikan masa depan agama yang lebih menggairahkan ${ }^{23}$. Internet dalam konteks komunikasi adalah sebagai jembatan penghubung antara satu pihak dengan pihak yang lainnya, tetapi dalam sudut pandang yang lain mengenai media bahwa media tidak hanya sebagai sarana penghubung namun bisa dikenal juga sebagai sebuah lingkungan yang khas $^{24}$.

Pandangan Meyrowitz tentang metafora media yang mengungkapkan fungsi media yang lebih dari sekadar sarana, tetapi juga sebagai Bahasa dan lingkungan. Pada lain pihak, konsep representasi juga beranggapan bahwa media memiliki cara kerja seperti Bahasa. Melalui media, kita dapat menyampaikan gagasan tentang sesuatu. Melalui internet, sebagai media baru dengan sejumlah keistimewaannya,

\footnotetext{
${ }^{21}$ Moch. Fakhruroji, "Dakwah Di Era Media Baru” Teori Dan Aktivisme Dakwah Di Internet.(Simbiosa Rekatama Media,2017) 28.

${ }^{22}$ Moch. Fakhruroji, "Dakwah Di Era Media Baru” Teori Dan Aktivisme Dakwah Di Internet, 187

${ }^{23}$ Moch. Fakhruroji, "Dakwah Di Era Media Baru” Teori Dan Aktivisme Dakwah Di Internet,109

${ }^{24}$ Moch. Fakhruroji, “Dakwah Di Era Media Baru” Teori Dan Aktivisme Dakwah Di Internet, 85
} 
Islam dapat direpresentasikan secara lebih bervariasi. Tidak hanya melalui teks dan audio-visual, tetapi juga dapat bersifat interaktif ${ }^{25}$.

Cara umat Islam dewasa ini dalam mempraktikkan Islam dengan menggunakan media baru 'internet' memiliki efek transformasional yang begitu besar, dunia yang lebih luas menjadi ajang dan sarana dalam merepresentasikan norma-norma keislaman, dan dalam mempersepsikan diri sendiri 'masyarakat Islam' menuju pihak luar tidak lepas dengan penggunaannya melalui internet. Secara etimologi, representasi berasal dari 'bahasa inggris' yang berarti penyederhanaan makna/arti lewat bahasa. bahasa merupakan media sebagai 'perantara' masyarakat dalam mencermati makna. Bahasa sebagai media representasi dapat menjadi acuan segala sesuatu yang penting untuk dimaknai. Dengan bahasa, symbol, tanda yang tertulis, ucapan secara lisan, maupun berupa gambar, adalah ungkapan mengenai bentuk pikiran ataupun konsep serta ide/pikiran terhadap sesuatu. Oleh sebab itu, pemaknaan kita atas sesuatu sangat bergantung pada bagaimana kita "merepresentasikannya". Nilai-nilai yang kita berikan untuk makna tertentu yang digunakan untuk merepresentasikan sesuatu dapat terlihat dengan jelas melalui katakata dan citra yang dibawa ${ }^{26}$.

Melalui proses representasi inilah kemudian kita dapat mengidentifikasi berbagai upaya umat Islam dalam mempertegas eksistensi mereka di cyberspace. Sebagian besar umat Islam menyadari sepenuhnya bahwa mereka dapat mengungkapkan bayangan diri mereka dalam cyberspace, tetapi tidak harus kehilangan jiwa mereka disana. Proses representasi Islam di internet pada akhirnya membuka wacana mengenai integritas moral umat islam yang didasarkan pada prinsip tauhid. Salah satunya tercermin melalui sejumlah upaya untuk menyaring sejumlah aplikasi atau konten yang "pantas" dalam konteks Islam sebagai bentuk

\footnotetext{
${ }^{25}$ Moch. Fakhruroji, "Dakwah Di Era Media Baru” Teori Dan Aktivisme Dakwah Di Internet, 135

${ }^{26}$ Moch. Fakhruroji, "Dakwah Di Era Media Baru” Teori Dan Aktivisme Dakwah Di Internet, 134
} 
literasi. Oleh sebab itu, literasi merupakan salah satu isu utama dalam hal representasi islam di internet ${ }^{27}$.

Berbicara mengenai Islam, erat kaitannya dengan dakwah media sosial. Dakwah pemuda jauh berbeda jika dibandingkan pada dakwahnya para orang tua, dakwah pemuda lebih aktif-selektif dalam mengangkat tema/pesan 'keagamaan' yang menurutnya dapat menunjukkan aspirasi para anak muda, ini menunjukkan bahwa dakwah pemuda juga jauh dari kata pasif. Perbedaan tersebut disampaikan oleh pendapatnya Linda Herrera dan Asef Bayat, memaknai para pemuda salah jika hanya atas dasar batasan usia mereka yang tentunya sangat berbeda terhadap sifat biologisnya, para anak muda tumbuh dan dibesarkan secara sosial sesuai dengan 'karakteristik sosio-psikologis' sesuai dengan perkembangan zaman yang mengikat waktu serta budaya. Dikehidupan sehari-hari, para pemuda sering kali melibatkan diri mereka dalam kegiatan politik sehari-hari maupun bernegosiasi terhadap orang dewasa, dan mereka bebas dalam mengukir dan mengekspresikan ruang sosialbudaya anak muda, para pemuda seringkali melakukan pemberontakan akan pendiriannya, dengan sendirinya subkultur akan terbentuk secara alami dikalangan anak muda, anak muda banyak melakukan inovasi, dan anak muda pun tidak jarang merasa sedikit khawatir terhadap status masa depannya akan seperti apa sebagai orang dewasa ${ }^{28}$.

Penulis telah mengamati secara detail bahwa akun@dakwahquransunnah itu tidak hanya menghadirkan atau merepresentasikan pesan-pesan agama yang berisi tentang pemikiran-pmikiran Persis, tetapi juga menghadirkan aspek-aspek sosial dan politik.

\footnotetext{
${ }^{27}$ Moch. Fakhruroji, “Dakwah Di Era Media Baru” Teori Dan Aktivisme Dakwah Di Internet, 138

${ }^{28}$ Asef Bayat dan Linda Herrera, ed., Being Young And Muslim: New Cultural Politics in The Global South and North (New York: Oxford University press, 2010), 6.
} 


\section{Aspek Sosial-Politik}

Persoalan mengenai kedudukan agama secara vertikal yang digaungkan oleh Persis tidak bisa lepas dari yang namanya kemanusiaan secara horizontal. Maka dari itu, akun@dakwahquransunnah mengandung unsur empati terhadap manusia yang sedang berada dalam kesempitan.

Gambar 4. Poster Donasi Bencana Alam di Tasik dan Garut Selatan

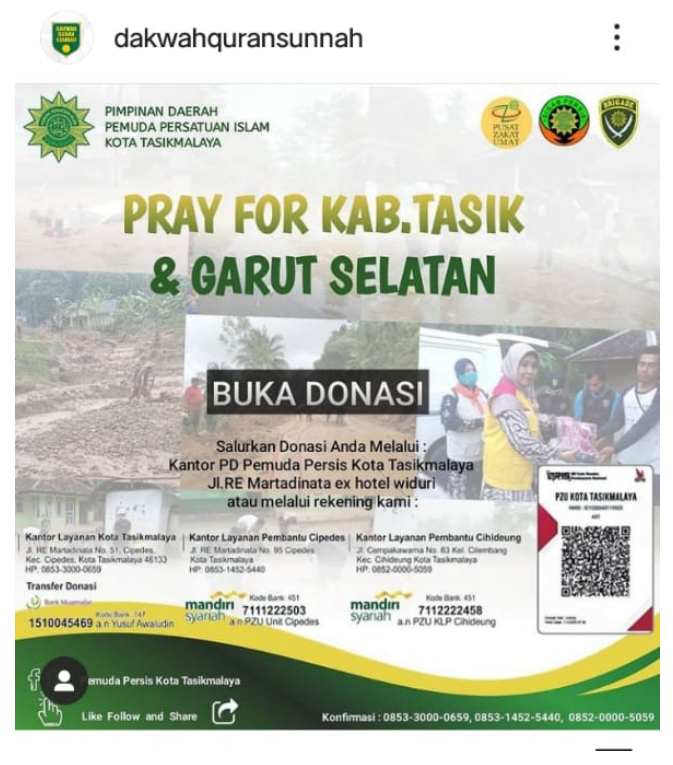

Sumber: Akuninstagram @dakwahquransunnah

Foto yang berisikan kepedulian terhadap sesama manusia yang tertimpa bencana. Diunggah pada tanggal 18 Oktober 2020. Dalam unggahan ini terdapat 167 like dan 0 komentar. Dalam unggahan ini terdapat caption dengan sebuah hadits yang bersumber dari Abu Hurairah:

Rasulullah bersabda: "barang siapa membantu seorang muslim dalam suatu kesulitan di dunia, maka Allah akan menolongnya dalam kesusahan pada Hari Kiamat. Dan barang siapa yang meringankan (beban) seorang muslim yamg sedang kesulitan, maka Allah akan meringankan (bebannya) di dunia dan akhirat". (HR Muslim No. 2699)

Meskipun dengan pokok-pokok pemikiran Persis yang kental akan akidah, ketauhidan dan fiqih, dengan kata lain adalah pemurnian ajaran Islam. Dalam dakwahnya Persis tidak melulu bergelut dengan hal tersebut, melainkan terbuka dan 
peduli terhadap hal-hal yang bersifat sosial. Ini menjadi bukti bahwa Persis juga lekat dengan jiwa kemanusiaannya sebagai warga negara.

Berbicara terkait dengan warga negara, Persis juga tidak menampik dengan persoalan politik. Hasil pengamatan pada akun instagram @dakwahquransunnah ini penulis menemukan bahwa Persis dengan ke khasannya yang kental, melalui media baru dan seiring dengan berjalannnya waktu, dalam dakwahnya tidak hanya mengenai tauhid, fiqih, aqidah. Tetapi juga dalam dakwahnya kerap berwacana mengenai sosial dan politik.

Gambar 5. Buletin At Taubah Edisi 11

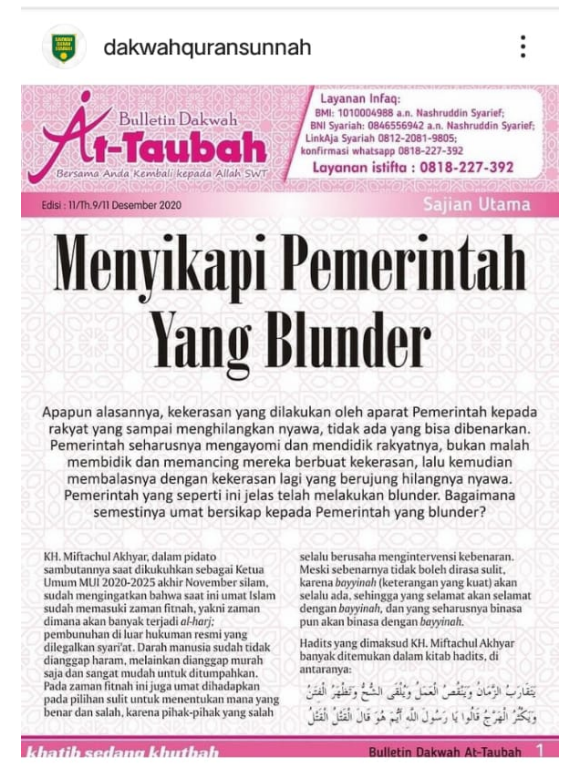

Sumber: Akuninstagram @dakwahquransunnah

Foto yang berisikan mengenai respon Persis terhadap Pemerintahan saat ini. Diunggah pada tanggal 10 Desember 2020. Dalam unggahan ini terdapat 110 like dan 0 komentar.

Foto pada unggahan tersebut diambil dari salah satu buletin dakwah milik Persis dengan nama buletin dakwah at-taubah. Foto ini diunggah secara up to date berisikan respon terhadap kasus bentrokan antara pemerintah dan ormas Islam FPI, dari semua unggahan dalam akun @dakwahquransunnah ini terlihat hanya satu unggahan yang mengandung unsur politik. Tentu ini menjadi perhatian warga net karena sedikit menyimpang dari kebiasaan Persis dalam mengunggah kontennya. 


\section{Kesimpulan}

Dari hasil analisis akun instagram @dakwahquransunnah ini penulis menemukan bahwa, satu; dalam konten dakwah Persis masih lekat dan tidak bisa lepas dari kekhasannya mengenai akidah, tauhid, dan fiqih, dimana Persis sebagai organisasi islam yang mengedepankan pemurnian ajaran Islam. Kedua; disamping Persis tetap dengan kekhasannya, dalam dakwahnya saat ini Persis mulai berbicara mengenai sosial ataupun politik. Ketiga; di setiap konten unggahannya terjadi pergeseran otoritas yang dilakukan oleh followers sebagai mad'u, ketika mereka berbicara di kolom komentar, seolah-olah mereka mempunyai kekuasaan sendiri untuk merespon konten tersebut. Ketika warga net setuju dengan isi unggahannya maka mereka akan secara otomatis me-like dan men-share kepada sahabat atau kerabatnya. Akan tetapi, jika warga net tidak setuju dengan isi kontennya maka mereka akan menghujatnya. Keempat; Persis kurang up to date dalam mengunggah konten dakwahnya, banyak konten konten yang sudah lama dan belum terbarukan dengan konten yang tengah menjadi pembicaraan hangat. Dan terakhir, kelima; Persis kurang mampu mengemas setiap konten unggahannya dengan menarik, padahal di jaman sekarang setiap lapisan masyarakat sudah menggunakan dan lebih dekat dengan teknologi sehingga Persis harus bisa menyeimbangkan dengan kemajuan jaman. Disisi lain konten yang dibawakan oleh Persis merupakan dakwah yang bersifat kuno (tidak ada kebaruan dalam konten dakwahnya).

\section{Daftar Pustaka}

Aflahal Misbah, "Kesenangan dan Otoritas Keagamaan: Sosialisasi Anti Musik di Instagram".Jurnal Masyarakat \& Budaya. Vol.21 No. 2. 2019, hlm:149 Asef Bayat dan Linda Herrera, ed., Being Young and Muslim: New Cultural Politics in the

Global South and North, (New York: Oxford University press, 2010.

Dadan Wildan Anas, Anatomi Gerakan Dakwah Persatuan Islam. tt: tp, 2015. 
Majalah Hudjdjatul Islam, "Bid'ah lebih berbahaya dari Ma'shiat", Bandung: Persatuan Islam. tt

Moch Fakhruroji, "Belajar Al-quran Kapan Saja, Dimana Saja: Kampanye Platform QuranCall PPPA Darul Quran melalui Instagram". UIN Sunan Gunung Djati, Bandung. Vol. 2 No. 2. 2020, hlm:397

Moch. Fakhruroji, "Dakwah Di Era Media Baru" Teori Dan Aktivisme Dakwah Di Internet.(Simbiosa Rekatama Media, 2017).

Moch. Fakhruroji., \& Muchtar, K. 2018. Campaigning \#golkarsolid: Branding Image Strategy of Golkar Party on Social Media. Atlantis Press.

Mulyana, Deddy (2017). Ilmu Komunikasi Suatu Pengantar. Bandung:PT. Remaja Rosdakarya.

Nabila Triyani P, "Personal Branding Selebgram Melalui Akun Instagram: studi deskriptif pada akun@NADYAROSMANIA ACCOUNT" jurnal Fakultas Komunikasi dan Bisnis Universitas Telkom. 2019, hlm: 77

Risalah, Bandung: Da'watul Islam \& Warta Jan'iyah PP. Persatuan Islam,th.XVIII No.184

Sunarwoto. Contesting religious authority: A study on Dakwah Radio In Surakarta, Indonesia. Desertasi, Tilburg University, 2015

Zulkifli, The ulama in Indonesia: Between Religious Authority and Symbolic Power. Jurnal Miqat, vol. XXXVII N0. 1 januari-juni 2013 